\title{
Urbanismo Tático como teste do espaço público: o caso das superquadras de Barcelona
}

Adriana Sansáo-Fontes. Universidade Federal do Rio de Janeiro, Rio de Janeiro, Brasil. Melisa Pesoa. Universidad Politécnica de Cataluña, Barcelona, Espanha.

Adelita Araujo-Souza. Centro Universitário Uniamérica, Foz Do Iguaçu, Brasil. Joaquín Sabaté. Universidad Politécnica de Cataluña, Barcelona, Espanha.

Larissa Neves. Universidade Federal do Rio de Janeiro, Rio de Janeiro, Brasil.

Resumo | Em 2013, a Prefeitura de Barcelona inicia um processo de transformação da mobilidade urbana com a proposta das superquadras. Mediante um projeto-piloto, ensaia a reuniáo de nove quadras do Plano Cerdá em uma unidade de $400 \mathrm{x}$ 400 metros, cujo interior restringe o tráfego veicular ao uso dos vizinhos. Podemos interpretar a intervenção como uma ação de Urbanismo Tático, liderada pelo poder público e com limitada gama de atores envolvidos, caracterizada pela implantação em fases de teste. Este artigo parte do questionamento de sua relativa novidade; conceitua brevemente o Urbanismo Tático; e discute sua abordagem "fase zero" e seu potencial de combinar açôes públicas e comunitárias. A análise do caso enfoca as etapas iniciais do projeto-piloto e as controvérsias geradas ao longo do processo. Reconhecendo que a proposta se baseia na requalificação do espaço público, a crítica principal está centrada na escolha do recorte e nos insuficientes processos participativos adotados.

PALAVRaS-CHAVE | espaço público, mobilidade, participação cidadã.

ABSTRACT | In 2013, Barcelona City Hall started the transformation of urban mobility with the superblocks proposal. A pilot project tested the grouping of nine blocks of the Cerdá Plan in a unit of $400 \times 400$ meters, inside which traffic is restricted to neighbors. Characterized by an implementation in test phases, the intervention can be interpreted as an action of Tactical Urbanism, led by the public sector and with a small range of stakeholders. This article starts from the questioning of its relative novelty, conceptualizes Tactical Urbanism, and discusses its "phase zero" approach and the potential to combine public and community actions. The analysis focuses on the initial stages of the pilot and in the controversies generated throughout the process. Recognizing that the proposal is based on the requalification of public space, the main criticism focuses on the choice of the pilot project site and the inadequacy of the participatory processes.

KEYWORDS | public space, mobility, citizen participation.

Recebido em 6 de dezembro de 2017, aprovado em 11 de julho de 2018.

E-mails: A. Sansāo-Fontes, adrianasansao@gmail.com | M.Pesoa, melisa.pesoa@upc.edu | A. Araujo-Souza, adelita.souza@uniamérica.br | J. Sabaté, joaquin.sabate@upc.edu|L. Neves, larineves9@gmail.com 


\section{Introduçáo}

Em 2013, a Prefeitura de Barcelona anuncia, com alarde, o início de um processo de transformação na ordenação da mobilidade urbana, um projeto conhecido como das supermanzanas (ou superquadras), ${ }^{1}$ que supostamente revolucionaria o funcionamento da cidade, ao agrupar e isolar do tráfego de veículos diversas quadras do emblemático Plano Cerdá.

Esta intervenção se apresenta com uma aura singular de inovação, formando parte de uma ação de Urbanismo Tático, caracterizada por um processo de implantaçáo em etapas, que considera duas fases iniciais de teste aplicadas para embasar a fase final de intervenção. Nesse sentido, nos indagamos, nesse artigo, se estas açóes táticas têm potencial para ativar espaços públicos e funcionar como fase zero em projetos de larga escala.

O primeiro ensaio da superquadra propóe uma unidade urbana resultante da reunião de nove quadras da rede viária ortogonal do Plano Cerdá, gerando uma única célula de 400 x 400 metros. $\mathrm{O}$ interior desta unidade compóe-se de quatro trechos de ruas pacificadas, ou seja, com tráfego reduzido e prioridade para pedestres e ciclistas. O projeto-piloto foi implantado no bairro de Poblenou com a premissa de que, a partir do estudo de pequenas partes da cidade, como integrantes de um todo, é possível abordar todos os tipos de relações: sociais, culturais, econômicas, políticas e ambientais.

A implantação de um projeto de pacificação viária requer uma grande mudança na forma como o espaço público é compartilhado entre veículos e pedestres. A pretensão de uma mudança supostamente radical na mobilidade de toda a cidade, que vem sendo apregoada em círculos técnicos há muitos anos, parte de alguns projetos pilotos, particularmente o da superquadra no Poblenou. É realizada com certa participação dos vizinhos (que, entretanto, logo se mostra insuficiente), e com a colaboração de estudantes de uma escola de arquitetura privada. Quatro trechos de rua são fechados no interior da mencionada superquadra, sendo reservados para pedestres, ciclistas e, pontualmente, para veículos de vizinhos e de serviço. São feitas delimitaçóes com jardineiras e pinturas na pavimentação, são dispostos brinquedos infantis e um mobiliário urbano elementar, propondo apropriaçóes alternativas das extensas áreas pavimentadas, que antes eram destinadas à circulação e estacionamento de automóveis e motocicletas. Segundo Rueda (2013), idealizador do projeto, os cidadáos passam a ser entendidos náo somente como pedestres, mas como atores principais das cidades, que ocupam sem limites o espaço público.

Essa ação tática, caracterizada como uma fase inicial de um projeto mais ambicioso operou como um teste, sendo aplicada em um bairro de baixa densidade com a pretensão de ser uma solução universal para a cidade. Em função dos resultados apresentados, se aplicará em larga escala com a finalidade de melhorar a mobilidade e, particularmente, as condiçóes ambientais (ruído e poluição). 
Baseado nesse caso, colocamos as seguintes questóes:

- Poderia essa ação ser considerada uma prática do Urbanismo Tático?

- É possível a articulação entre temas de grande escala, como mobilidade e meio ambiente, com uma abordagem de pequena escala como o Urbanismo Tático?

- Como o Urbanismo Tático pode colaborar com o planejamento urbano em larga escala?

Argumentamos que para o êxito de um projeto de grande escala é necessária e fundamental a articulação entre as propostas do poder público "de cima para baixo" com as açôes da população local "de baixo para cima".

Adotamos como metodologia a pesquisa documental baseada em artigos científicos e comentários na mídia, a análise in loco da etapa intermediária de implantação e as entrevistas com alguns atores envolvidos no projeto. ${ }^{2}$

$\mathrm{O}$ artigo está estruturado da seguinte forma: inicialmente se questiona a relativa novidade das medidas propostas, para, na sequência, apresentar uma breve conceituação do Urbanismo Tático, seguida de uma discussão a respeito dessa abordagem como fase zero de implantaçáo e como possibilidade de combinação entre açóes do poder público e da sociedade. Posteriormente é feita a apresentação detalhada do caso, focada em suas etapas iniciais de implantação.

\section{Superquadras: nada de novo debaixo do sol}

O que primeiro convém destacar é a "relativa novidade" do instrumento.

Como já nos dizia Rafael Moneo: “... inventar, 'inventar’ de verdade, só o fizeram três grandes arquitetos no mundo. $\mathrm{O}$ resto, o que temos que fazer é aprender a copiar bem".

Dizemos isso porque a ideia das superquadras é tão antiga como a própria concepção do Ensanche. Cerdá concebeu uma malha relativamente homogênea, uma vez que confere medidas ou inclinaçóes diferentes a diversas vias, como Paseo de Gracia, Rambla Cataluńa e Avenida Diagonal, e ruas, como Aragón, Urgel ou Paseo San Juan, entre outras. Mas, se observarmos com cuidado, podemos verificar uma ordem implícita de agrupamento de nove quadras, na qual a quadra central estava inicialmente reservada a equipamentos. Com o processo de execuçáo do Ensanche estes equipamentos desapareceram, mas é mantido implicitamente algo desta ordem, reconhecível na largura maior de várias vias verticais, particularmente as que, ao leste da Praça das Glorias, cruzam sobre a Gran Vía. ${ }^{3}$

Foram realizadas três entrevistas, duas com integrantes da plataforma contrária ao projeto e uma com um integrante da plataforma favorável ao projeto. Também coletamos depoimentos de atores relacionados ao poder público (BCN Ecología) e à faculdade de arquitetura envolvida (UIC). Ainda, foram analisadas discussóes que ocorreram na mídia, uma vez que a temática teve ampla cobertura, inclusive internacional.

3 Avenida segregada que transcorre em nível inferior, unindo a parte superior e inferior do bairro. 
FIgURA I | Esquemas interpretativos do Plano Macià (GATCPAC), onde se verifica a ideia de superquadra (superior) e novo traçado de ruas de um módulo de 400 x 400 m encontrando o Plano Cerdà, Plano Macià (GATCPAC), 1934 (inferior)
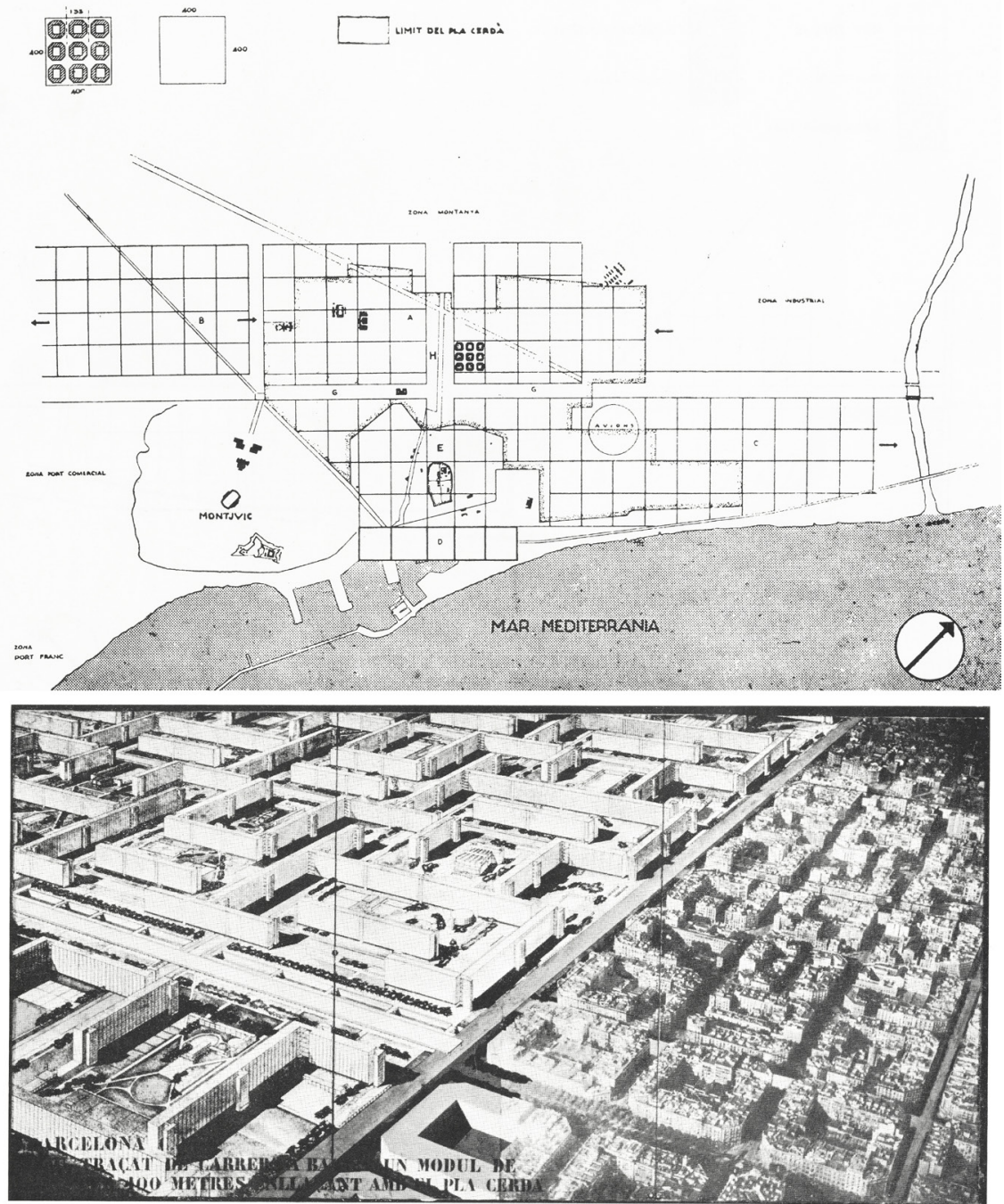

FONTE ANY CERDÀ. DISPONÍVEL EM: HTTP://WWW.ANYCERDA.ORG/WEB/ES/ARXIU-CERDA. ACESSO EM DEZ/2OI7 
Muito mais radical é a proposta do GATCPAC, ${ }^{4}$ junto com Le Corbusier, conhecida como Plan Macià. ${ }^{5}$ Nela, Le Corbusier e Sert agrupam as quadras, mantendo para o tráfego de veículos uma a cada três ruas, tanto na vertical, como na horizontal, substituindo a edificação em quadra fechada por uns redents, blocos longitudinais que vão se dispondo, dentro desses agrupamentos, paralelos ou perpendiculares às novas ruas, passando, pontualmente, sobre as horizontais.

Embora este projeto não tenha sido executado, podemos dizer que ele permaneceu gravado no imaginário dos urbanistas barceloneses. Prova disso é o posterior projeto da Gran Vía, que mantém uma via, a cada três que a atravessam, com largura maior que as restantes. Além disso, diversos outros projetos posteriores, particularmente aqueles relativos à ordenação do transporte, foram realizados com essa hierarquia derivada do agrupamento de quadras.

Tampouco é inovadora a ideia da pedestralização em Barcelona. Em 1973 essa premissa começa a ser adotada no centro histórico, fechando para o tráfego de veículos a Avenida de Portal del Ángel. No fim da década de 1990, após o êxito dessa primeira iniciativa, é criada a primeira ilha comercial exclusivamente reservada para pedestres, Barnacentre, no norte do bairro Gótico (delimitada pela Rambla, Vía Layetana, ruas Fontanella e Ferrán). Não existiam, nesse momento, muitos precedentes no mundo, sendo Barcelona uma das pioneiras, juntamente com cidades alemãs como Munique ou Essen, ou outras na Suécia, Canadá e no Brasil, em Curitiba, com o projeto do calçadão da rua Xv de Novembro, em $1972 .{ }^{6}$

A ilha comercial de Barcelona chega a contemplar 23 ruas e praças totalmente pedestralizadas ou de tráfego restrito durante o horário comercial. Posteriormente, foram pedestralizadas muitas outras áreas ou foi pacificado o trânsito, com a redução da velocidade e restrição de passagem em determinados horários.

É evidente que a ideia de superquadras vai muito além de uma estratégia de pedrestralização. Seu principal valor, que pode ser observado tanto nas propostas atuais, quanto nos planos Cerdá e GATCPAC, reside na possibilidade de repetição de uma malha em maior escala, diversa da escala das quadras tradicionais da cidade, na forma de um sistema.

Náo é, portanto, o agrupamento de quadras, nem a pedestralização de uma área urbana, o que acrescenta novidade ou distingue a política das superquadras. Analisaremos, então, outra de suas dimensôes, o que podemos identificar de Urbanismo Tático.

Grupo de Arquitectos y Técnicos Catalanes para el Progreso de la Arquitectura Contemporánea (GATCPAC), movimento arquitetônico desenvolvido na Catalunha nos anos de 1930, coincidindo com a Segunda República Espanhola. Seu objetivo era promover a arquitetura de vanguarda, principalmente o racionalismo, encontrando-se com as correntes europeias que se desenvolviam naquele momento. O grupo se formou em Barcelona em 1929, e seus principais membros foram Josep Luis Sert, Josep Torres Clavé, Antoni Bonet Castellana e Raimon Duran Reynals.

5 Neste projeto urbanístico, desenvolvido entre 1932 e 1935, Josep Luis Sert e Le Corbusier propóem uma nova ordem geométrica para o Ensanche, com grandes eixos estruturadores como a Gran Vía, a Meridiana e a Paralela, e uma nova fachada marítima composta por arranha-céus com várias alas.

6 O projeto de Jaime Lerner defende a rua comercial e de pedestres desde 1970, sendo uma referência mundial nesse sentido. 


\title{
Urbanismo Tático como fase zero
}

O conceito de Urbanismo Tático é recente e significa a abordagem para construção e ativação de uma vizinhança, usando intervençóes e políticas de curto prazo e baixo custo, que permitam a imediata recuperação, redesenho ou programação do espaço público, visando futuras transformaçóes.

O termo "tático", segundo Lydon e Garcia (2015, p. 2) se refere às açôes de pequena escala que servem a grandes propósitos. Urbanismo Tático seria, portanto, segundo seus precursores, uma abordagem que utiliza açôes rápidas e de fácil execução, através de pequenas intervençôes, para demonstrar possibilidades de mudança em longo prazo e larga escala, significando uma resposta rápida para circunstâncias específicas do século xxi (Duany, 2015, p. xi).

O Urbanismo Tático não é um movimento unificado, mas uma rubrica geral por meio da qual se pode captar uma ampla gama de projetos urbanos emergentes (Brenner, 2018, p. 9), sendo uma abordagem passível de uso por uma série de atores, incluindo governos, empresas, ONGs, grupos de cidadãos e indivíduos (Lydon \& Garcia, 2015, p. 2) para iniciar novos espaços ou reparar espaços existentes. As ações "faça você mesmo" (do inglês "do it yourself" - DIY), em que os próprios cidadãos demonstram as possibilidades de mudança, têm sido as mais difundidas, e alguns autores, como Brenner (2016) a consideram a real forma de mobilização do Urbanismo Tático. Segundo ele

\begin{abstract}
o urbanismo tático é mobilizado "de baixo para cima" através de intervenções organizacionais, culturais e ideologicamente diversas para enfrentar as questóes urbanas emergentes. Os designers profissionais, bem como governos, desenvolvedores e corporaçôes, em geral, podem participar e estimular ativamente o urbanismo tático. Mas, suas fontes geradoras devem estar fora do controle de qualquer ideologia específica de especialistas ou qualquer instituição específica, classe social ou coligação política. (Brenner, 2016, p. 9)
\end{abstract}

No entanto, segundo Lydon e Garcia (2015, p. 16), a ação tática também pode ser iniciada pelo poder público para testar ideias que serão futuramente implantadas e medir sua aceitação pela comunidade, sendo esta a sua terceira aplicação mais comumente utilizada: o Urbanismo Tático como fase zero de implantação. Nessa utilização, os espaços são reservados para as futuras intervençôes através de uma ação temporária que pode trazer benefícios imediatos, oferecendo a oportunidade da incorporaçáo de dados qualitativos e quantitativos ao projeto definitivo, em um processo de tentativa e erro. Dessa maneira, a abordagem surge na tentativa de romper o impasse e morosidade do grande planejamento, atuando através de projetos e políticas flexíveis e ajustáveis, sem perder de vista o longo prazo e os objetivos em grande escala (Lydon \& Garcia, 2015, p. 3).

O grande desafio, portanto, estaria em combinar satisfatoriamente as açóes "de cima pra baixo" e "de baixo pra cima" de forma a tornar o processo de planejamento mais orgânico e, ao mesmo tempo, mais ágil. 
Seria o projeto das superquadras um exemplo de Urbanismo Tático, de ação capitaneada pelo poder público que insere etapas táticas e temporárias no processo, buscando a articulação com a comunidade?

Não passa despercebida a quantidade de faixas estendidas nas janelas dos edifícios da superquadra manifestando oposição, e em alguns casos, apoio, à implantação do projeto. $\mathrm{O}$ fato à primeira vista pode parecer surpreendente, porém, revela que o tema é sensível e vem gerando controvérsias entre a comunidade local.

FIGURA 2 Imagens de protestos em relação à superquadra

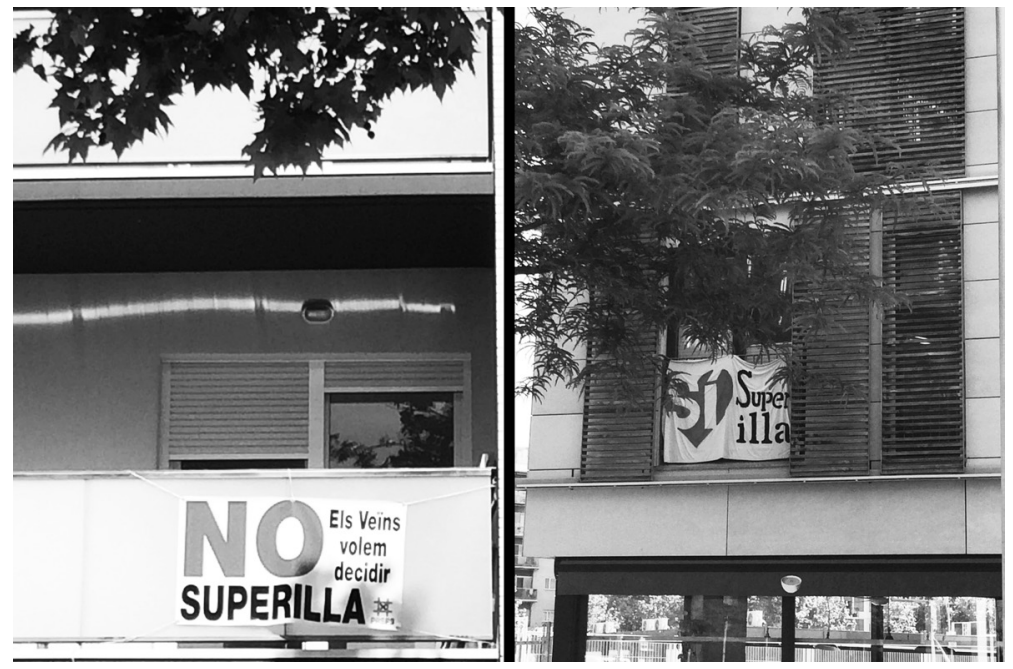

FONTE ELABORAÇAO PRÓPRIA, ABRIL (20I7)

FIGURA 3 | Manifestação contra a superquadra em 17 de março de 2017

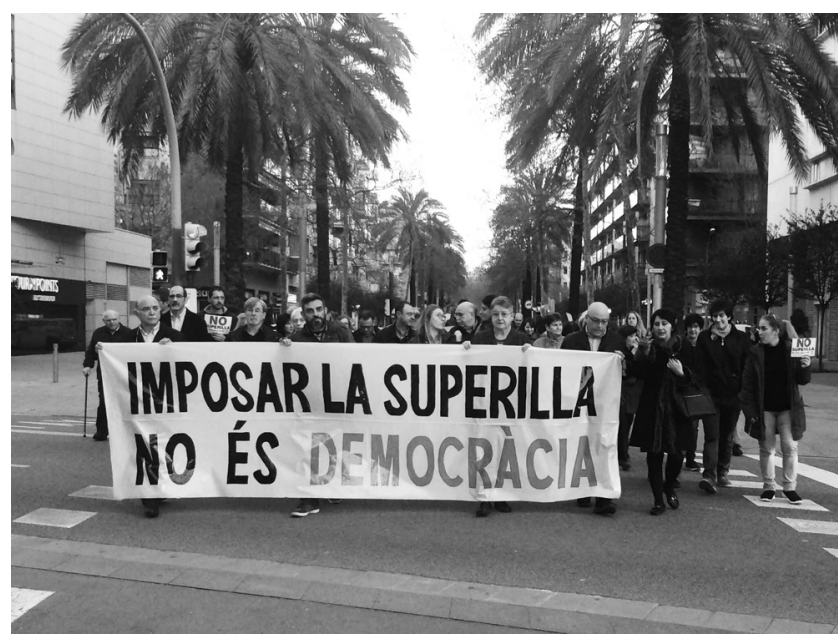

FONTE SUPERILLA BCN. DISPONÍVEL EM: HTTPS://SUPERILLABCN.WORDPRESS.COM/2OI7/O3/I3/DELALIANCA-A-VALENTI-ALMIRALL-ELS-VEINS-ENTREGUEN-FIRMES-PER-ATURAR-LA-SUPERILLA/ ACESSO EM DEZ/2OI7 


\section{O caso das superquadras de Barcelona}

\section{Contexto}

Barcelona, com algo mais de 1,6 milhóes de habitantes (Ajuntament de Barcelona, 2016), é a segunda maior cidade da Espanha e a décima primeira da União Europeia. O plano de expansão da cidade para além das muralhas, do engenheiro Ildefonso Cerdá (1859), tem como característica principal a multiplicação de uma unidade morfológica básica, a quadra, em uma rede relativamente homogênea. Com dimensóes de 113 x 113 metros, delimitadas por edifícios em seu perímetro, de altura e profundidade homogêneas e chanfros de 20 metros nas esquinas, as quadras estáo dispostas em uma grelha contínua, separadas por ruas de 20 metros e avenidas de 30 até 100 metros.

As transformações do Plano Cerdá ao longo de seu processo de implantação, que alteraram gabaritos, profundidades de edifícios e natureza dos espaços livres internos às quadras, resultaram em uma cidade extremamente densa e com insuficiente quantidade de espaços livres públicos. Aliado a essas características, o fluxo pesado e uniforme de veículos ao longo da quadrícula contribuiu para os altos graus de contaminaçáo do ar da cidade nos dias atuais. Os níveis de dióxido de nitrogênio (NO2) e de partículas superam em ao menos 1,3 vezes os níveis recomendados pela oms (Agencia de Salud Pública, 2016). O tráfego, a mobilidade e a contaminaçáo figuram entre as dez preocupaçôes centrais dos barceloneses (Márquez, 2017).

De forma a enfrentar o tema da escassez de espaços públicos e da contaminação, a Prefeitura de Barcelona elaborou um novo Plano de Mobilidade Urbana para o período de 2013-2018, visando reduzir o uso de veículos e ampliar a quantidade de espaços públicos para uso de pedestres e ciclistas. Nesse contexto se introduzem as superquadras. Dentro dessa nova estrutura, além dos trechos de ruas pacificados, cujo limite de velocidade é $30 \mathrm{Km} / \mathrm{h}$, os cruzamentos internos, já dilatados pelos chanfros das esquinas do Plano Cerdá, são potencializados como novas áreas de lazer de grandes dimensôes - praças-, buscando incrementar a quantidade de área verde, que hoje no Ensanche é de $1,3 \mathrm{~m}^{2}$ por habitante ${ }^{7}$, para cumprir a recomendação da oms de $10 \mathrm{~m} 2 /$ hab.

\section{Projeto}

A implantação do projeto das superquadras foi possível graças a uma mudança de governo na prefeitura de Barcelona, na qual, dentro da nova equipe, alguns membros tiveram algum tipo de envolvimento com trabalhos de superquadras. Assim, se

7 "Barcelona tem 3.611 hectares de verde que representam 35,3\% da superfície municipal (dados de 2009). Desses hectares, 1.076 são de verde estritamente urbano, 1.795 correspondem ao registro municipal dentro do Parque Natural de Collserola e 740 são de verde privado e se encontram situados majoritariamente na zona alta da cidade. Esta superfície equivale a $17,71 \mathrm{~m}^{2}$ de espaço verde por habitante $\left(6,64 \mathrm{~m}^{2}\right.$ em trama urbana, sem contar Collserola). A dotação global de zonas verdes é, portanto, bastante boa, mas somente $30 \%$ dela é estritamente pública e urbana. Os hectares restantes correspondem ao verde privado (20\%) -que contribui para esponjar a cidade e traz benefícios ambientais, mas não oferece possibilidades de uso público-, e ao verde florestal do registro municipal de Barcelona dentro de Collserola (50\%)” (Ajuntament de Barcelona, 2013). 
buscava uma proposta geral para toda a cidade e a realização de uma primeira superquadra piloto (a do Poblenou), além de outras cinco posteriores: "duas das cinco novas superquadras estarão situadas no Eixample, uma no bairro de Sant Antoni e outra à esquerda do Eixample; uma no Camp Grassot, em Gracia; uma em Horta, e uma em Les Corts" (Sust \& García, 2016. Tradução nossa).

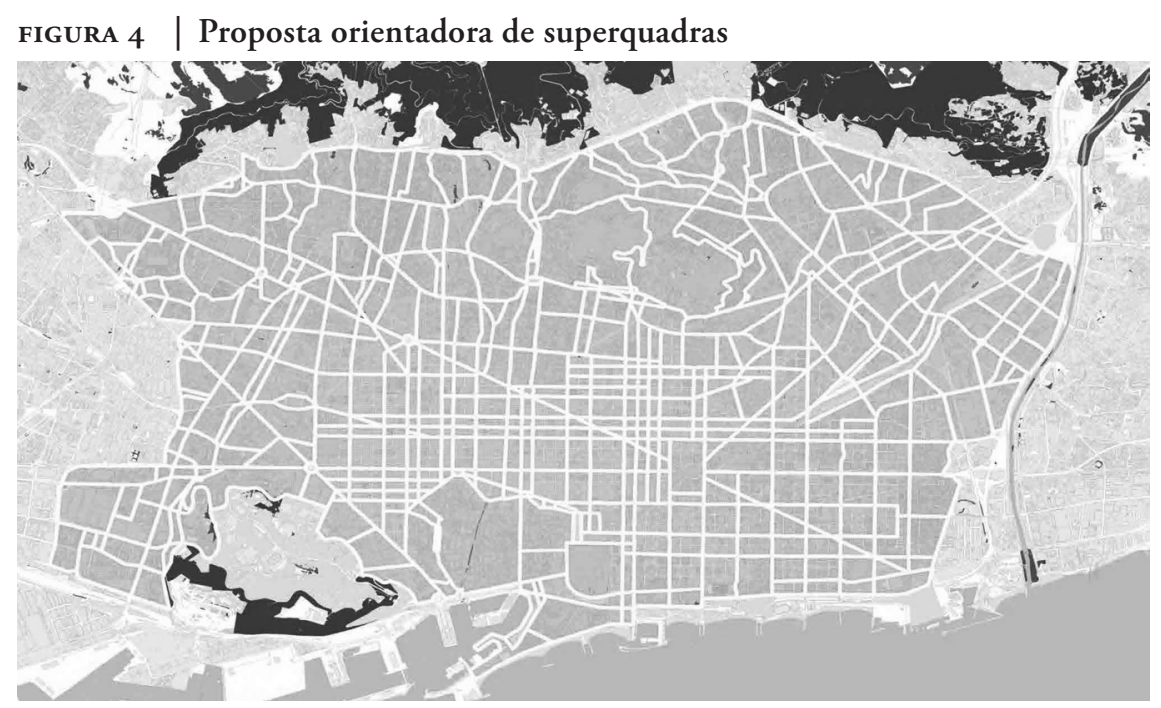

FONTE PLA DE MOBILITAT URBANA DE BARCELONA 2OI3-2OI8. BCN ECOLOGIA. DISPONÍVEL EM: HTTP://AJUNTAMENT.BARCELONA.CAT/SUPERILLES/ES/CONTENT/DOCUMENTACION. ACESSO EM DEZ/20I 7

A primeira superquadra foi executada no Poblenou, bairro histórico de origem industrial, que vem sofrendo um processo de transformação com a construção de novos edifícios e reabilitação de imóveis históricos, sendo, até o momento, um local de baixa densidade populacional e pouca circulação. ${ }^{8} \mathrm{O}$ bairro está localizado entre a Gran Vía, uma das principais avenidas da cidade, e a orla. O projeto piloto foi implantado nas nove quadras delimitadas pelas ruas Badajoz, Pallars, Llacuna e Tánger, que estão localizadas a duas quadras da Avenida Diagonal e da Praça das Glórias. O projeto piloto servirá como um teste para a replicação da superquadra em vários bairros, universalizando o modelo no Ensanche e ampliando suas áreas de pedestres.

8 A superquadra se encontra no bairro de San Martí, e localiza-se entre dois bairros delimitados pela Prefeitura, Llacuna e Poblenou. Estes bairros apresentam características diferenciadas, principalmente no que tange ao uso residencial: Poblenou apresenta em 2017 27,6\% de uso residencial, enquanto Llacuna 17,9\% (como referência, o Ensanche direito apresenta 53,6\% de uso residencial e Les Corts 46,2\%). (Ajuntament de Barcelona, 2016). 
FIgURA 5 | Localização da superquadra do Poblenou

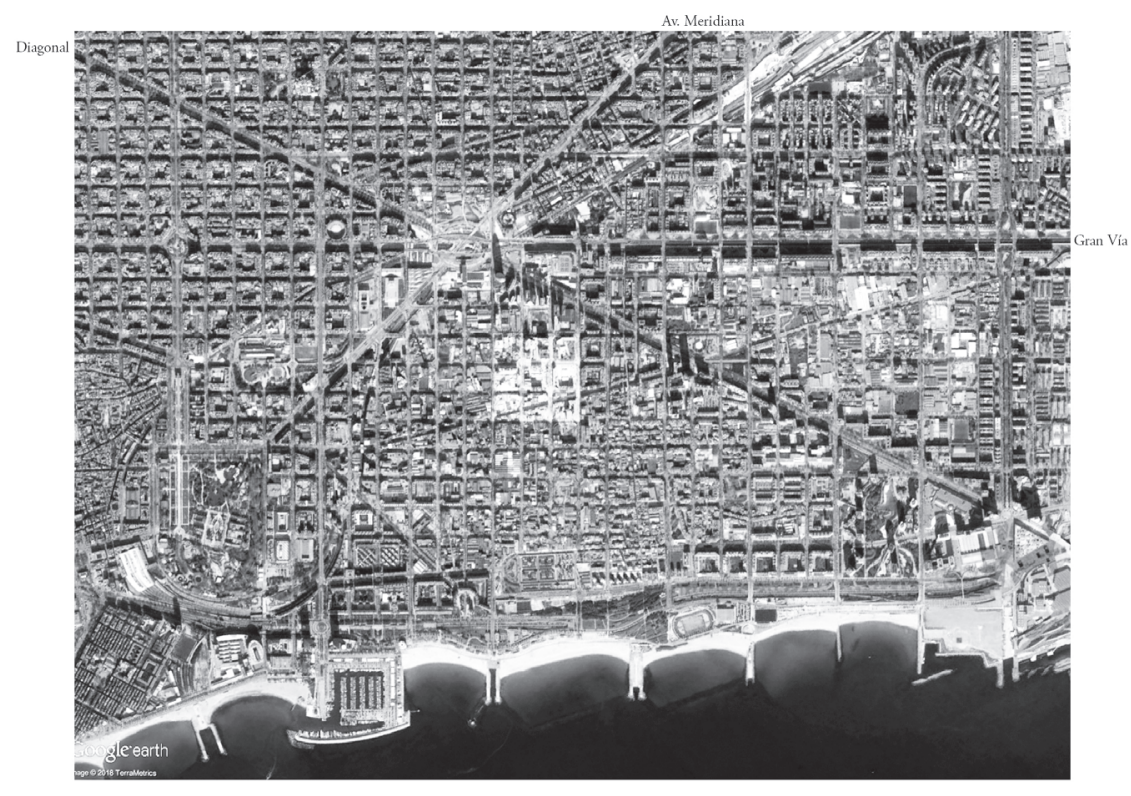

FONTE ELABORAÇÃo PRÓPRIA COM BASE EM GOOGLE EARTH (20I8)

Salvador Rueda (2013) defende a adoção da grelha viária de 400 x 400 metros como a solução que melhor se adapta aos propósitos do transporte motorizado, minimizando o impacto por ele gerado. Entretanto, o autor não diminui a importância da unidade básica da quadra para a vida urbana. Diz ele que:

A quadra tem um comprimento que se acomoda às caminhadas. De fato, em um itinerário é possível mudar de direção para a direita ou esquerda ou até mesmo seguir na mesma direção a cada 80, 90 ou 100 metros, ou seja, a cada cruzamento. Esta realidade física tem um efeito psicológico positivo que permite escolher rotas diferentes para se chegar ao mesmo destino. Não seria o mesmo se em vez de 100 metros as quadras tivessem, digamos, $2 \mathrm{~km}$. As caminhadas reduziriam drasticamente, como também reduziria o número de atividades diante das fachadas. A paisagem urbana se empobrece e, com ela, os incentivos para o deslocamento a pé (Rueda, 2013, p. 17).

$\mathrm{O}$ autor sustenta que as vias náo deveriam estar -todas- a serviço do veículo de passagem:

Um dos maiores erros cometidos com a aparição do automóvel foi dar a ele passagem livre em todas as seçôes de rua da cidade formal, como se fosse um móvel com as mesmas características dos já existentes. Um grande erro! (Rueda, 2013, p. 18). 
FIgura 6 | A superquadra do Poblenou, delimitada pelas ruas Badajoz, Pallars, Llacuna e Tánger, compreendendo trechos das ruas Sancho de Ávila e Almogàvers (horizontais) e Ciutat de Granada e Roc Boronat (verticais)
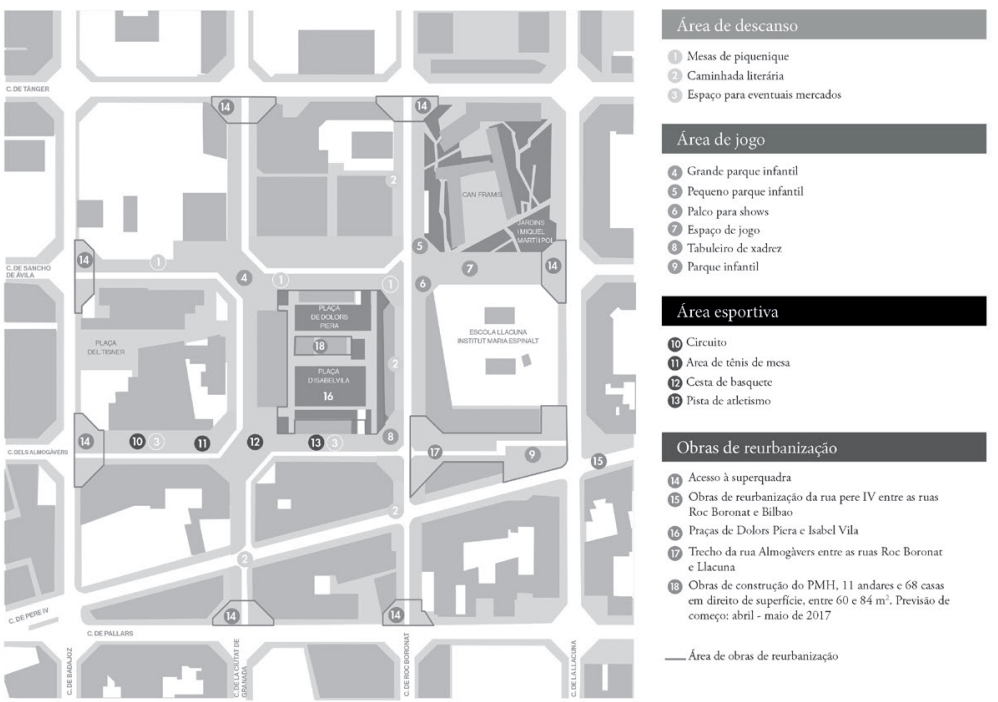

Fonte AJUNTAMENT DE BARCELONA. Disponível EM: hTtP://AJUNTAMENT.BarCelona.CAT/ SUPERILLES/CA/SUPERILLA/SANT-MARTI. ACESSO EM DEZ/2OI7

FIGURA 7 Reconfiguração da circulação na superquadra

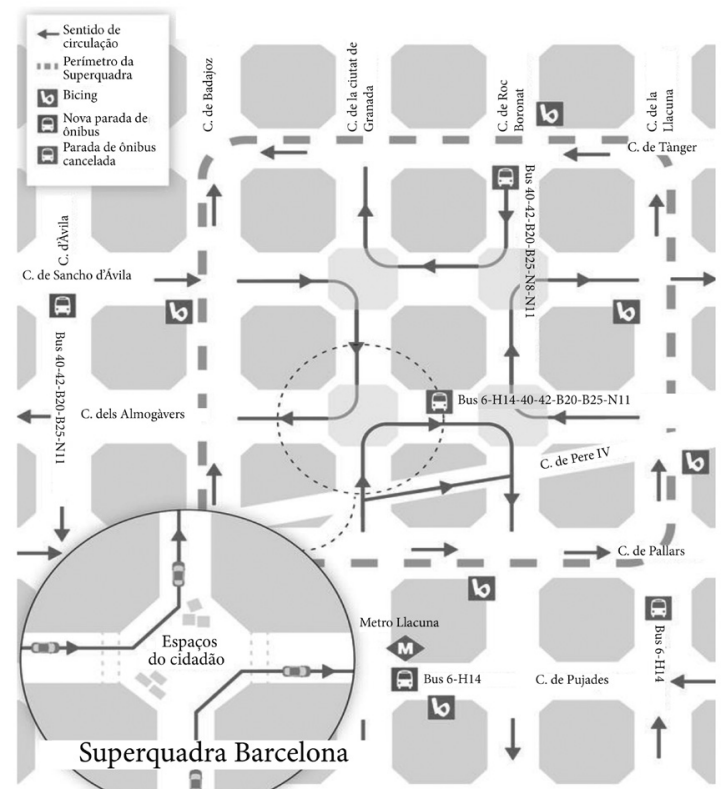

Fonte MARIONA ASÍN, AJUNTAMENT DE BARCELONA. Disponível EM ARA.CAT: HTTPS://WWW.ARA. CAT/SOCIETAT/BARCELONA-RECONFIGURARA-SUPERILLA-QUEIXES_O_I 649235205 .HTML. ACESSO EM SET/2OI 8 


\section{Atores envolvidos}

Já diria De Certeau (1999, p. 101) que a tática é a arte do fraco, determinada pela ausência de poder, enquanto a estratégia é organizada pelo postulado de um poder. Segundo Lydon e Garcia (2015, p. 9), estratégias e táticas têm igual valor e deveriam ser combinadas, uma vez que os planejadores (poder) precisam de táticas para acelerar a implantação dos projetos, o que demanda a articulação satisfatória das açóes "de cima pra baixo" e "de baixo pra cima".

No caso da superquadra, o poder foi combinado com uma gama talvez excessivamente limitada de atores sociais. O poder público é o responsável pelo projeto, através da Agência de Gestão Ecologia Urbana (empresa pública constituída pela Câmara Municipal de Barcelona, Conselho Provincial de Barcelona e Região Metropolitana $\mathrm{BCN}$ ) e pela execução, através da Câmara Municipal de Barcelona. Existem, na vizinhança, duas plataformas que tiveram relaçóes com o poder público, uma favorável ao projeto, o Coletivo Superilla Poblenou (Collectiu Superilla), e outra contra sua implantação, a Plataforma dos Afetados pela Superilla (Plataforma d'Afectats per la Superilla), ambas somam aproximadamente duzentos e cinquenta apoiadores cada.

Sobre a real representatividade dos interlocutores e a eficácia do processo participativo, as opiniôes são controversas. Segundo fontes do governo, entre os meses de fevereiro e setembro de 2016 foi realizada uma série de reuniōes entre a Prefeitura de Barcelona, os representantes de uma escola de arquitetura (UIC), a associação de moradores do Poblenou, a Taula Pere IV (associaçáo de vizinhos e coletivos da região), o Institut de Arquitectura Avanzada de Cataluña (IAAC), as associaçóes de empresas Poblenou Urban District e 22@ Network, e a Agencia de Ecología Urbana de Barcelona (Rueda, 2016).

Posteriormente, entre 5 e 12 de setembro de 2016, foi realizada uma oficina liderada por uma universidade privada (Universitat Internacional de Catalunya), cujo objetivo era finalizar com uma instalação física no local, que pudesse responder às necessidades reais discutidas nas reunióes. Ainda segundo fontes do governo, durante a etapa 2, a Câmara Municipal de Barcelona realizou consultas periódicas aos moradores e trabalhadores para avaliar o desempenho do projeto e discutir, em conjunto, propostas para fortalecê-lo.

Usos temporários costumam minimizar o dilema da falta de participação. Nesse sentido, intervençóes "mão na massa", como as açóes postas em prática pela oficina, puderam testar o espaço com baixo custo, pensando em futuras transformaçóes (Oswalt et al, 2013, p. 14). No entanto, embora a intervenção tática "fase zero" (etapas 1 e 2 do processo) tenha, segundo as fontes oficiais, apostado na participação da vizinhança, os representantes de ambos os coletivos - a favor e contra o projeto criticaram que o processo de implantação da superquadra ocorreu de maneira súbita, sem suficiente consulta prévia à vizinhança. 


\section{Processo de implantação}

Segundo Feireiss e Hamm (2015, p. 28), instalações urbanas são como laboratórios onde é possível examinar processos. A fase temporária da superquadra atuou nesse sentido, ajudando a explorar o território e testar sua adaptação a diferentes usos.

$\mathrm{O}$ processo de projeto da superquadra do Poblenou se divide em três etapas. A etapa 1, que teve a duração de 15 dias, representa as açóes táticas de curta duração, de caráter mais "festivo", voltadas à esclarecer a população sobre as possibilidades desses aproximados $20 \mathrm{mil} \mathrm{m} 2$ de espaços livres. Nessa etapa, os espaços sofreram intervençôes temporárias através de ações reversíveis, ou seja, medidas de gestão, mobiliário, pintura e revitalizaçáo das áreas, tais como a inserção de parques infantis, mesas de piquenique, áreas de descanso e circuitos de jogos. A etapa 2, com duração de 6 meses, representa o estágio intermediário de média duração, no qual o traçado da etapa final já está lançado, porém, realizado de forma interina e com baixo investimento, estando a etapa voltada a permitir a convivência da população com as mudanças e avaliar seus impactos. Essa etapa apostou em uma superquadra multifacetada, sediando também atividades de bairro, tais como feiras, mercados e projetos culturais. Já a etapa 3 representa as reformas estruturais de caráter duradouro, consolidadas após as análises das duas etapas anteriores.

Para esse artigo, consideramos as duas etapas táticas (etapas 1 e 2) como a "fase zero" de implantação, etapas que antecipam as reformas estruturais posteriores (etapa 3).

\section{Etapa 1 (curta duraçâo)}

No projeto piloto, foram definidos para as vias internas pacificadas da superquadra cinco usos distintos: esportivos, infantis, culturais, atividades de bairro e de permanência.

A oficina de uma semana propôs que cada cruzamento interno das ruas Tànger, Laguna, Pallars e Badajoz tomasse como ponto de partida um direito civil para potencializar suas particularidades: cultura, democracia, intercâmbio e lazer. A intenção era propor uma reflexão sobre a natureza do espaço público, a apropriação do espaço, o lugar, a ordem e escala urbana, a ação participativa, os sistemas de reciclagem e os novos ciclos de vida, além de ter como meta reduzir, nessa primeira etapa, $11 \%$ dos veículos motorizados na superquadra.

O cruzamento "Cultura", localizado na interseção entre ruas Sancho de Ávila e Ciutat de Granada, teve como principal intervenção a unificação das calçadas com a caixa de rua, através de uma pintura de piso homogênea utilizando os "panots", motivos presentes na pavimentação da cidade, em tamanho aumentado. A proposta, por meio desse elemento de fácil identificação, era demonstrar que todo o espaço agora passava a ser de domínio dos pedestres. A nova área de convívio também foi complementada com assentos móveis que usam a mesma geometria do desenho de piso.

A ação tática no cruzamento "Democracia", localizado na interseção entre as ruas Almogàvers e Ciutat de Granada, fundamentou-se na transformação de sua

9 As informaçôes dessa primeira etapa foram fornecidas pela uIC (Universitat Internacional de Catalunya), através do material do Taller Vertical 2016, contendo as pranchas com as propostas para os quatro cruzamentos internos da superquadra. 
ambiência em um lugar de reunião, participação e expressão, baseada na tipologia do "parlamento". Pinturas no piso criaram as demarcaçóes espaciais principais, sendo a ação complementada com a instalação de um muro de expressão, urnas de votaçáo, cadeiras, pallets e um parlatório, permitindo diferentes configuraçóes.

O cruzamento "Intercâmbio", na interseção Roc Boronat-Almogàvers, se destinou a dar suporte a um espaço de trocas: de bens, habilidades, serviços e opinióes. Os usos pensados para materializar a ideia foram o mercado de escambo, a economia colaborativa e os postos de massagem, que se utilizaram da combinação de diferentes tipos de mobiliário: bancos de concreto, mesas de massagem, bancos de madeira e mesas de mercado.

Finalmente, o cruzamento "Lazer", localizado na interseção de duas ruas de grande influência, Roc Boronat e Sancho de Ávila, considerou a redução da caixa de rua de três faixas para somente uma, promovendo uma velocidade reduzida e destinando o restante da área a uma praça, que foi dividida em várias áreas de entretenimento, de forma a atender a demanda da população de diferentes faixas etárias. Para a divisão deste espaço foram construídas paredes de pneus, de baixa altura, que executaram várias funçôes: serviram como assento, como locais de cultivo e de jogos.

\section{Etapa 2 (média duração)}

Após a realizaçáo da etapa 1, que teve curta duraçáo, algumas intervençóes se mantiveram na fase de teste, de média duração, até que as transformaçôes de caráter duradouro (etapa 3) começassem a ser implantadas. Apesar das divergências que possam ser despertadas por esse planejamento temporário, Feireiss e Hamm (2015, p. 54) defendem que o benefício potencial é certamente o de permitir o teste de novas possibilidades em experiência espacial e construtiva, devido à sua pequena escala e curto prazo.

Nesse sentido, podemos destacar algumas transformaçóes, iniciadas ou continuadas na etapa 2, tais como: redução de 7\% dos estacionamentos na superfície (50 dos 700 foram eliminados); desvio do fluxo de passagem de veículos para os limites da superquadra, liberando as ruas internas para pedestres e ciclistas; redução do limite de velocidade para $10 \mathrm{~km} / \mathrm{h}$ nas ruas internas, com permissão de passagem somente para veículos de emergência, de carga e de moradores; liberação de cerca de 8 mil m² para praças, área antes tomada por veículos, permitindo a criação de parque infantil, palco para atividades culturais, quadras esportivas, pista de atletismo e áreas de convivência; instalação de mobiliário urbano como: locais para sentar, bicicletários, mesas de ping pong e de picnic; instalação de ponto de recarga de carros elétricos e; distribuição de vegetação ao longo de toda a superquadra (Martínez, 2016).

Desde a inauguração da superquadra, os novos espaços para pedestres vêm sendo tomados por eventos que estimulam a ocupação das ruas, fomentando a coesão social, bem como um estilo de vida mais saudável, menos sedentário e ao ar livre. Já aconteceram encontros de coletivos para apresentar trabalhos e pesquisas, como o evento "Compartim Coneixement Col-lectiu", realizado em junho de 2017 na rua Roc Boronat; cinema ao ar livre, com a exibição do documentário Roger \& Me, de Michael Moore, realizado em maio de 2017; comemoração do Festival de Maio (Festes de Maig a la Superilla Poblenou) nos dias 19 e 20 de maio de 2017, reunindo 
atividades como exposiçóes de projetos de arquitetura do prêmio Mies Van de Rohe, yoga, dança, mercado de trocas, gincanas infantis, brincadeiras com água e jogos com materiais reciclados, além de um jantar coletivo e shows de música; festivais como o Open Day, em maio, que ofereceu uma ampla gama de atividades culturais, sociais e de cunho empresarial para promover a arte e criatividade; bem como fóruns de discussão, como o compartilhamento do videogame "Superbairro", que, no mês de março, deu a cada usuário a oportunidade de projetar seu próprio bairro em 15 minutos por meio de uma interface simples e intuitiva. Esses eventos foram organizados por instituiçóes, como o IAAC, associaçôes culturais, como Ojo Cónico, ou pelo próprio Coletivo Superilla Poblenou, entre outros ativadores da sociedade civil.

FIGURA 8 A superquadra em funcionamento na etapa 1, no cruzamento das ruas Sancho de Ávila com Ciutat de Granada (esquerda) e na etapa 2, na rua Ciutat de Granada, entre as ruas Tánger e Sancho de Ávila (direita)

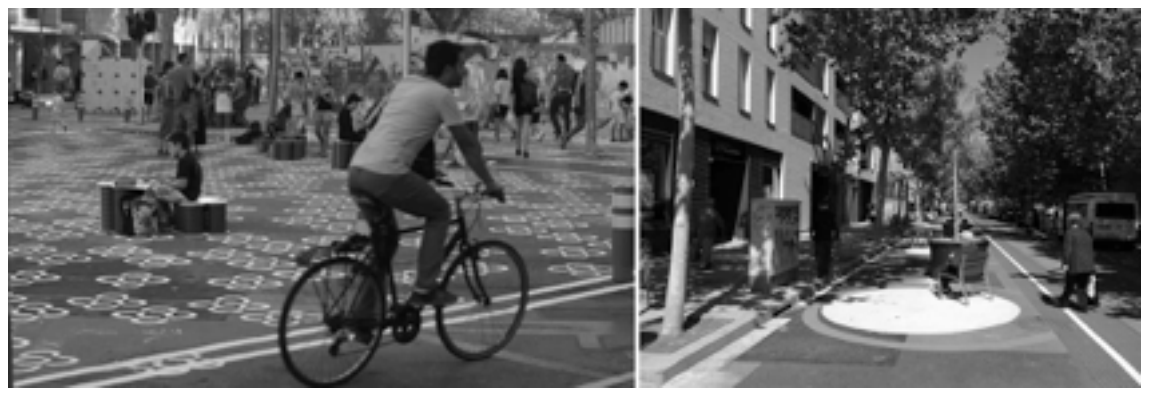

FONTE EL PERIÓDICO, DISPONÍVEL EM: HTTP://WWW.ELPERIODICO.CAT/CA/BARCELONA/20 I 6 I 2 I 9 / CIU-ERC-PROPOSTA-CANVI-SUPERILLA-5700472. ACESSO EM DEZ/2OI7 (ESQUERDA) E AUTORES, ABRIL/2OI 7 (DIREITA).

A implementação das duas primeiras etapas, isto é, das açôes táticas, teve o custo inicial de 425 mil Euros e a intenção de abrir caminho para açóes estruturantes de caráter permanente (etapa 3).

\section{Etapa 3 (longa duraçâo)}

As ações da etapa 3 começaram no mês de abril de 2017 com a construção do edifício de Habitação Pública Municipal, localizado na área central da superquadra, que conta com 11 pavimentos e 68 apartamentos de 60 a 84 m² (Nació Digital, 2017).

Como continuidade dessa etapa, está prevista a urbanização da rua Almogàvers, entre Laguna e Roc Boronat, com presença significativa de nova arborização e de zonas de estar e lazer, onde pretende-se reduzir substancialmente a quantidade de veículos, liberando cerca de $3.410 \mathrm{~m}^{2}$. Também se planeja a urbanização de dois novos locais na quadra central, atualmente terrenos náo utilizados: as praças Dolors Piera e Isabel Vila. A intervenção prevê uma área verde de $8.273 \mathrm{~m}^{2}$ incluindo horta urbana de gestão comunitária e espaços de estar. Por fim, serão removidos os veículos que atualmente ocupam a Praça Tísner, de forma a recuperar o espaço para uso dos moradores (Nació Digital, 2017). 


\section{Um balanço dos primeiros efeitos}

As superquadras se inserem em um processo de desenvolvimento das cidades que, ao invés de ampliar as larguras de ruas, sucumbindo ao protagonismo do automóvel, reduz o tráfego de veículos e força uma mudança de hábitos. Entretanto, mudanças radicais são sempre conflituosas. Por essa razão, surgiu um movimento contrário ao projeto, a Plataforma dos Afetados pela Superilla, que reúne os atores sociais descontentes. Por outro lado, o Coletivo Superilla Poblenou é um grupo criado em apoio ao projeto, defendendo as novas formas de apropriação do espaço público e evidenciando seus benefícios para a vizinhança.

A partir da análise do projeto e das entrevistas realizadas, é possível organizar as críticas em cinco questôes primordiais, que se referem tanto ao projeto piloto no bairro do Poblenou quanto à própria ideia da superquadra para a cidade de Barcelona.

\section{Escolha do local: baixa densidade $x$ alta densidade}

A primeira crítica desfavorável se refere ao projeto piloto, mas contém críticas aplicáveis a outros locais. A questão levantada é a própria escolha da área específica do Poblenou como local de teste do projeto. Os integrantes da Plataforma de Afetados afirmam que a região já possui uma elevada proporção de área verde por habitante e que não há necessidade de interromper os fluxos de veículos em eixos básicos de circulação, como as ruas Pere IV e Almogàvers, para conquistar mais áreas verdes. Sobre a própria visão da cidade mais verde, com menos poluição, mais pedestres e menos carros, os entrevistados defendem que a situaçáo do Poblenou se difere de outras áreas de pedestres de Barcelona, já que o bairro não necessita uma ação emergencial para conter seu adensamento, mas sim o contrário: a superquadra tem baixa densidade de comércio, tráfego e edifícios.

Nesse sentido, cabe explicitar que, no Ensanche central, a definição formal das quadras de Cerdá é muito clara, caracterizada pela edificação perimetral e por esquinas claramente definidas, os famosos chanfros de 20 metros de fachada. Costumam ser quadras de marcada densidade residencial e intensidade de atividades, o que garante um uso intenso em todos os momentos do dia. A superquadra escolhida, no entanto, não obedece aos mesmos padróes. Por um lado, sua imagem é muito fragmentada, com edifícios isolados que náo fecham o perímetro. Por outro, a rua Pere IV introduz um corte em algumas quadras, o que impede uma leitura clara da estrutura da superquadra. Além disso, a densidade residencial e o número de atividades são muito baixos, o que náo contribui para o aproveitamento, durante a semana, dos benefícios da ausência de tráfego.

A superquadra forma parte do sector 22@ Sul (entre as ruas Badajoz, Pallars, Llacuna e Tánger), cuja densidade residencial representa apenas a metade da densidade do Poblenou e a quinta parte do Ensanche. O plano vigente admite apenas 0,3 $\mathrm{m}^{2}$ de residência por $\mathrm{m}^{2}$ de solo. $\mathrm{O}$ resultado é a quase inexistência de habitaçóes nas nove quadras escolhidas, ao mesmo tempo em que seis delas possuem indústrias, oito contam com comércios, seis contém escritórios e em duas foram construídos hotéis. A metade da superfície de tais quadras está dedicada a equipamentos e espaços livres. ${ }^{10}$

10 Estes dados procedem do Sistema d'Informació Geogràica "El Poblenou de Barcelona_sectors 22@”, realizado pelo escritório cCRs junto com Júlia Corominas, para el Ayuntamiento de Barcelona, 2018. 
FIGURA 9 | Comparação entre a ocupação das quadras Eixample e da superquadra Poblenou
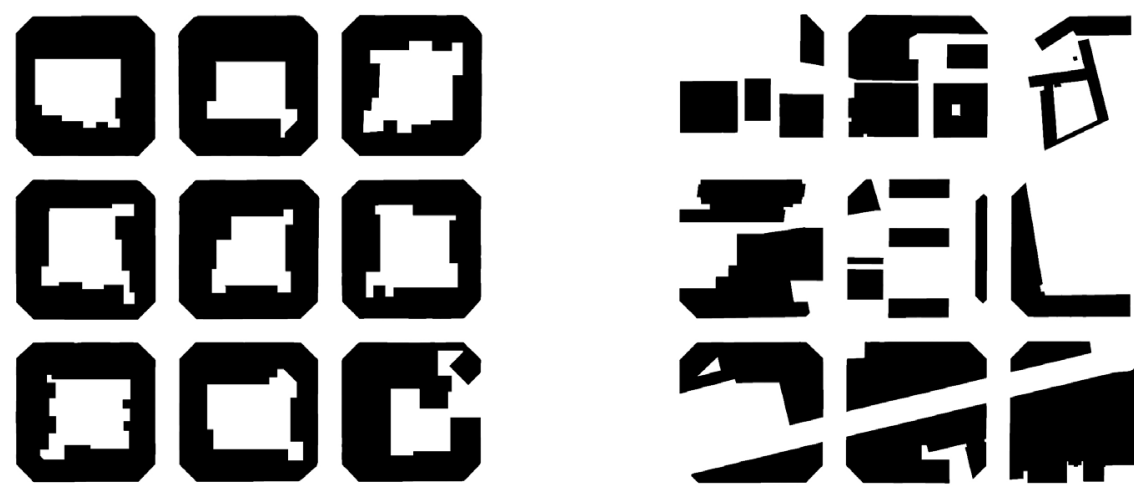

FONTE ELABORAÇAO PRÓPRIA

FIgura io | Características de ocupaçáo e atividades na superquadra Poblenou

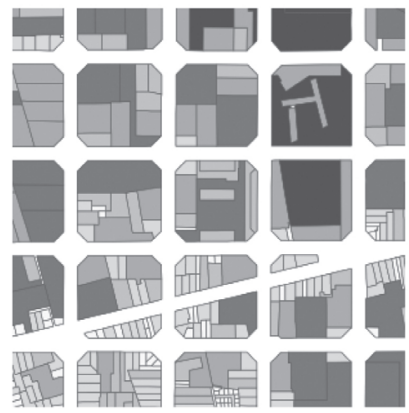

Superfícic $\left(\mathrm{m}^{2}\right)$

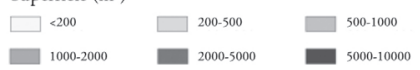

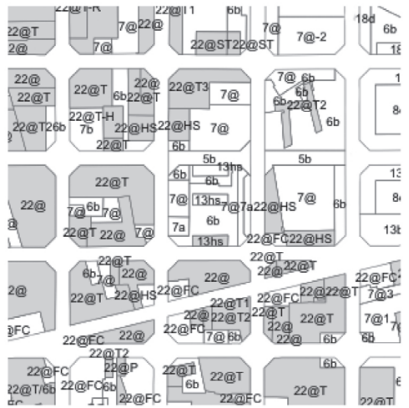

Areas22@

$\square 22 @$
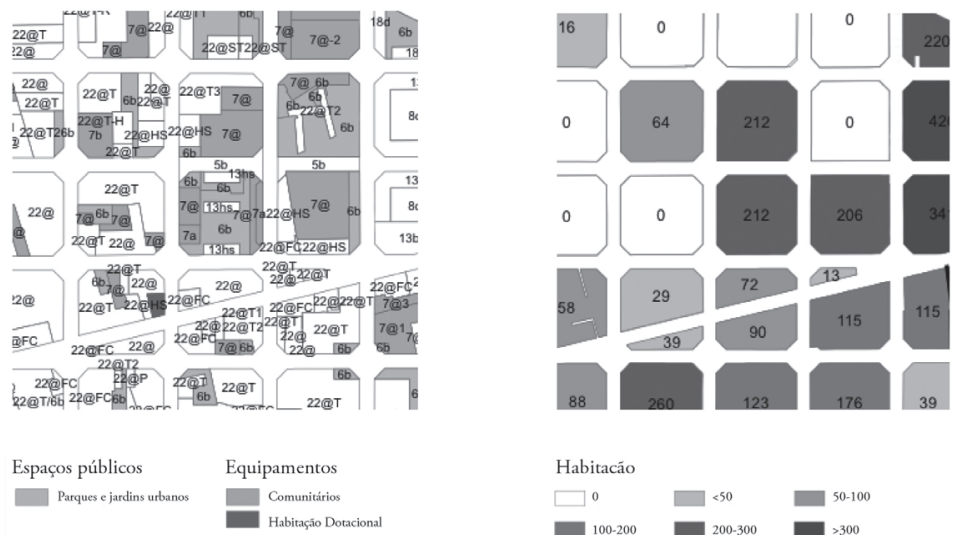

Habitacáo

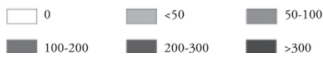


Foram constatadas opinióes divergentes quanto às atividades realizadas desde a pacificação das ruas. Para um dos integrantes do Coletivo Superilla Poblenou, o espaço é ocupado espontaneamente por vizinhos e cidadáos, que agora podem, longe de motos e carros, apropriar-se e identificar-se com ele. Já a integrante da Plataforma dos Afetados pela Superilla afirma que não se desenvolvem atividades contínuas na área e que esta se encontra frequentemente deserta. De fato, em nossa atividade de campo, percebemos a pouca apropriação no horário diurno, em dia útil, e talvez isso se deva à baixa densidade e à ausência de um térreo ativo confrontante, uma vez que há muitos terrenos vazios e algumas edificaçóes sem atividades no térreo. Segundo a entrevistada, esporadicamente, comemoram-se aniversários e realizam-se algumas refeiçôes na rua por intermédio do Coletivo Superilla Poblenou. Outro integrante da Plataforma dos Afetados afirma que jovens se reúnem para beber e que as atividades são raras, geralmente subsidiadas direta ou indiretamente pela prefeitura. Segundo ele, um desses eventos, o Festival Open Day, atraiu pessoas de fora do bairro e terminou em sujeira e desordem.

Cabe acrescentar que boa parte do Poblenou está sendo transformado com uma densidade de cerca de quarenta habitaçóes por hectare. Trata-se de uma densidade excessivamente reduzida para um âmbito central da cidade, o que ocasiona problemas de todo tipo: insuficiente proporção de habitação social, de mistura urbana, expulsão de população com menos recursos, predomínio de usos terciários, desertificação a partir de certa hora da tarde; problemas fundamentais que a prefeitura deverá corrigir em breve. Porém, a ausência de espaços livres, a congestáo das ruas, o excesso de tráfego e a derivada contaminaçáo, não são precisamente questóes preocupantes, o que significa que o modelo das superquadras parece ter sido proposto para afrontar problemas inexistentes.

\section{Participaçáo e processo "de baixo para cima"}

Um dos principais pontos críticos do projeto, que não se restringe ao projeto piloto, mas se aplica ao processo como um todo, parece ter sido a interlocução entre os atores sociais e o poder público. Os entrevistados da Plataforma de Afetados pela Superilla afirmaram que o motivo da sua rejeição se originou na ausência, segundo eles, de um procedimento democrático de consulta para implementação do modelo, restando apenas como opção discutir a modificação do projeto, e não a sua posta em prática. Outra crítica colocada foi o curto tempo em que o projeto foi implantado, impedindo uma discussão mais aprofundada de seus fundamentos. O próprio poder público reconhece que talvez a divulgação para os vizinhos, a respeito das mudanças na mobilidade, tenha sido tardia, prejudicando a aprovação do projeto pelos moradores.

Projetos urbanísticos táticos fundamentam-se na democracia participativa porque visam a promover a coesão social e não são formalmente pré-programados ou impostos "de cima para baixo" (Brenner, 2016, p. 9). Ainda que mobilizados pelo poder público, devem buscar articulaçôes comunitárias, negociaçôes e alianças, aprimorando os modelos participativos.

De fato, a proposta, embora seja largamente conhecida em círculos profissionais, foi aplicada com certo caráter de improvisação, sem realizar trabalho pedagógico 
suficiente e sem sequer ser reclamada seriamente a partir da base. Quase poderíamos supor que se decidiu verificar a validade de uma ideia geral em um âmbito em que se supốe que não criará graves alteraçóes, uma vez que não existem graves conflitos de mobilidade a serem afrontados, e, assim, supóe-se que haverá pouca resistência. Também se presumia que a implantação de um protótipo de superquadra em uma zona central da cidade poderia gerar fortes conflitos e um custo político muito maior.

\section{Alteração do Ensanche}

Os impactos do projeto após seis meses de testes dividem opinióes. Segundo a Plataforma de Afetados pela Superilla, os impactos são negativos, pois se observa o aumento de tráfego no perímetro, o que transforma as ruas ao redor em caminhos de evacuaçáo da superquadra; o aumento do percurso para entrada e saída do bairro, através do efeito loop, já que os motoristas precisam dar mais voltas para retornar às suas casas; o aumento da poluiçấo sonora e do ar nas ruas do perímetro; e a dificuldade de entrada de serviços de ambulância e bombeiros, que precisam deslocar mais para chegar aos mesmos lugares. Outra questão levantada pelo coletivo é o conflito do projeto da superquadra com o plano da rede de transportes, já que a empresa de transporte municipal forçou a superquadra a abrir uma das ruas internas para parada de ônibus. Ou seja, o projeto se choca com o plano da rede de transporte público.

Para o membro do Coletivo Superilla Poblenou, a quebra da isotropia das ruas do Plano Cerdá é preocupante, mas é necessária, e o modelo urbano existente permite isso. Segundo ele, os impactos do projeto são positivos, pois resultaram na melhoria da qualidade de vida em várias dimensões: menos ruído, poluição e perigo, e mais espaços abertos, verdes e livres, além do reconhecimento da importância e os benefícios de apostar na mobilidade por bicicletas e saber promovê-la por meio de uma rede de infraestrutura e equipamentos.

Já vimos que o projeto de Cerdá considerava de forma implícita certo agrupamento de quadras e uma hierarquia das ruas perimetrais de tais possíveis agrupamentos. Estes não eram sempre de três por três quadras, mas resultam facilmente reconhecíveis no projeto. O problema não radica, portanto, nesse ponto, mas no fato de que, para se apostar hoje em dia em dita transformação, com tal ambição e características, deve haver o acompanhamento de um conjunto de medidas prévias ou paralelas, tais como uma potencialização e reordenamento do transporte público (ônibus e metrô); um impulso muito mais determinado no uso da bicicleta ou da caminhada; um desincentivo ao uso do veículo privado; e, fundamentalmente, uma intensa campanha pedagógica após o debate de um pormenorizado plano global de aplicação faseada. Exatamente o contrário do ensaio esquemático realizado em um âmbito supostamente tão pouco conflitivo quanto necessitado das medidas ensaiadas.

E, ainda, deve aplicar-se, com coragem, em âmbitos que necessitem de tais correções, por sua considerável congestão e contaminação; em âmbitos com uma marcada legibilidade como Ensanche, e não em contextos como a área escolhida do Poblenou, onde há ausência de uma clara configuração de quadras Cerdá, que, pela existência de numerosos espaços livres e blocos isolados, faz desaparecer a configuração de ruas do Ensanche e diminui a legibilidade urbana. 


\section{Gentrificação}

Outro tema que veio à tona com o projeto piloto das superquadras foi o da gentrificação que ocorreu em paralelo, supostamente causada pela valorização das áreas residenciais e comerciais. Entendemos como gentrificação o processo de chegada de classes profissionais, ou pessoas com maior poder aquisitivo, que acaba encarecendo o custo de vida na área, desde aluguéis até bens e serviços, provocando a expulsão de economias mais frágeis.

Um membro do Coletivo Superilla Poblenou chama atenção para o impacto do projeto na avaliação dos terrenos, em razão da melhoria da qualidade de vida associada a esse modelo urbano. Talvez essa pessoa esteja reconhecendo indícios de um fenômeno que vem afetando o conjunto do Poblenou há poucos anos.

Mas isso, longe de ser atribuído à restrição de tráfego que a superquadra propóe, tem sua origem em fatores próprios do processo original de transformação do bairro. Entre estes, destacamos a aposta quase exclusiva em atividades inovadoras, que utilizam o conhecimento e o talento como principal recurso produtivo. Estas incluem pesquisa, projeto, edição, cultura, gestão de bases de dados ou atividades multimídia. Todas têm em comum o uso intensivo do espaço, da informação e comunicação, e a atração de pessoas qualificadas que buscam entornos de qualidade, infraestruturas e espaços especializados e flexíveis. É questão de tempo a desaparição das atividades industriais e de oficinas, do comércio tradicional, de tudo que caracterizava um bairro popular. Se a isto somamos uma densidade residencial e uma proporção de habitação social insuficientes, o resultado é determinante para a gentrificação. E, nesse sentido, a contribuição da superquadra em si ao processo de modificação da base populacional é praticamente irrelevante.

\section{Mudança de hábitos}

A mudança de hábitos é outra crítica colocada ao projeto, que, todavia, é muito comum a qualquer situaçáo de interferência na zona de conforto de distintos grupos sociais. Segundo o membro do Coletivo Superilla Poblenou, a razáo para a rejeição de parte dos moradores ao projeto é a resistência a uma mudança muito profunda no modelo urbano e, portanto, no estilo de vida da sociedade. Apesar das consequências, ele sustenta que estamos muito acostumados a viver entre os carros, motocicletas, ruído, poluição e pouco espaço para viver, brincar e crescer. Prevalece o medo da mudança, a negação dos graves problemas associados ao atual modelo de mobilidade, e a necessidade de responsabilizar os outros por nossos problemas, neste caso, o governo. Na sua visáo, vencer o medo de mudança dos moradores, as pressôes dos lobbies de carros e motocicletas e a politização dos defeitos por parte da oposição do governo são os desafios atuais do projeto.

Trata-se, certamente, de uma observação carregada de senso comum, que nos remete, uma vez mais, a uma característica que deveria ser própria de qualquer ação de Urbanismo Táctico: surgir predominantemente da base e vir acompanhada de um intenso esforço pedagógico sobre suas consequências. 


\section{Conclusão}

A superquadra é um exemplo de intervenção contemporânea que aposta em um projeto aberto e gradual, que valoriza a fase zero como campo de mudança, revisão, questionamentos e até mesmo de reversão ao estado original. É uma oportunidade de abrir espaço às pequenas intervençôes experimentais, especulativas e participativas, consideradas como simples instrumentos táticos, mas que podem ser inseridas em um projeto maior, visando alteraçôes profundas na forma com que vem sendo pensada a cidade, comprovando a viabilidade da colaboração das açôes de pequena escala no processo de se pensar a grande escala.

Estaria o projeto aproveitando de fato essa oportunidade? Questóes relacionadas aos cinco pontos discutidos acima persistem, e vale refletir sobre alguns desdobramentos.

Poderiam os novos espaços ser melhor apropriados? Em locais de baixa densidade e em transformação como o Poblenou, incentivos aos térreos comerciais, à comida de rua e às atividades locais poderiam auxiliar nessa apropriaçáo. Em locais de média e alta densidade, um maior envolvimento da sociedade na escolha dos lugares para implantação das superquadras poderia acelerar o processo, aliviando as controvérsias.

Poderia o processo ser mais participativo? Acreditamos que o excesso de centralização prejudica a implantação do projeto. Alternativas como o maior envolvimento de instituiçóes locais do que de entidades externas ao bairro; o mapeamento de grupos locais que promovem açóes na vizinhança; a integração dos moradores não somente no processo de decisão de como o espaço será usado, mas também na própria discussão sobre sua viabilidade, auxiliarão no maior equilíbrio entre as açóes "de cima pra baixo" e "de baixo pra cima", minimizando o controle do processo pelo poder público.

Poderiam os impactos ser melhor medidos? Ferramentas de medição e análise de dados anteriores e posteriores à implantação da proposta podem servir como argumentos para dirimir impasses. Medir a qualidade do ar, a poluição sonora, a quilometragem rodada, o número de acidentes, ou seja, traduzir os impactos em números, a exemplo de atuações semelhantes em outras cidades, poderia equalizar discursos opostos.

Poderiam, os processos prévios de transformação, manter seus moradores originais? São necessárias medidas preventivas para conter a gentrificação, e o reforço do envolvimento dos vizinhos com o projeto, o congelamento de aluguéis e a reserva de espaço para edificaçóes de interesse social são alternativas que poderiam auxiliar nesse sentido.

É possível uma mudança de hábitos? Esta talvez seja mais desafiadora das metas, que só pode ser alcançada por meio do mais amplo diálogo com a sociedade, que deixe claros os benefícios de transformaçóes radicais nas formas de ver e usar as ruas. Mas, certamente, uma mudança de hábitos é mais que necessária se pensamos na estratégia de superquadra como uma atuação replicável, como se propóe, ao longo de toda a cidade e em diferentes bairros. Perguntamo-nos, por isso, como se 
adaptarão esses processos participativos, e se será possível gerar produtos suficientemente diferenciados, mas com certa legibilidade unitária na soma das estratégias.

Possivelmente as consequências negativas, os desajustes, e, portanto, as críticas, não cabe atribuí-los ao conceito em si, ao agrupamento de quadras e hierarquização de vias, às medidas de restrição do tráfego em algumas delas para dedicar mais espaço aos vizinhos, aos visitantes e a atividades como o lazer e o passeio. Foi pior que um pecado, foi um erro, nos diria o conhecido escritor Jorge Luís Borges. E, efetivamente, o erro radica na má eleição de um projeto piloto no local e momento equivocados.

\section{Referências bibliográficas}

Agencia de Salud Pública (2016). Informe de Evaluación de la Calidad del Aire en Barcelona. Disponível em: https://www.aspb.cat/wp-content/uploads/2017/05/Avaluacio-de-laqualitat-aire-a-la-ciutat-de-barcelona-2016-PRV_170502.pdf

Ajuntament de Barcelona (2013). Plan de Movilidad Urbana (2013-2018). Disponível em: http://ajuntament.barcelona.cat/ecologiaurbana/es/que-hacemos-y-porque/ movilidad-activa-y-sostenible/plan-de-movilidad-urbana

Ajuntament de Barcelona (2013). Plan del Verde y de la Biodiversidad de Barcelona 2020. Disponível em: http://ajuntament.barcelona.cat/ecologiaurbana/sites/default/files/ PlanVerde_2020.pdf

Ajuntament de Barcelona (2016). Estadística. Disponível em: http://www.bcn.cat/estadistica/ castella/dades/tpob/pad/ine/a2016/sexe/bcn.htm. Consultado em 26/05/2017.

Ajuntament de Barcelona (2017, 12 de abril). L'Ajuntament de Barcelona finalitza la prova pilot $i$ avança en la implantació dels usos definitius de la Superilla de Poblenou [Servicio de Prensa]. Disponível em: http://ajuntament.barcelona.cat/premsa/2017/04/12/ lajuntament-de-barcelona-finalitza-la-prova-pilot-i-avanca-en-la-implantacio-delsusos-definitius-de-la-superilla-de-poblenou/. Consultado em 26/05/2017.

Archivo Cerdá (2009). Any Cerdà. Disponível em: http://www.anycerda.org/web/es/arxiucerda. Consultado em 01/12/2017.

Brenner, N. (2016, dezembro). Seria o "urbanismo tático" uma alternativa ao urbanismo neoliberal? Revista e-metropolis, 7(27), 6 a 18. Disponível em: http://emetropolis.net/ artigo/201?name=seria-o-urbanismo-tatico-uma-alternativa-ao-urbanismo-neoliberal

Cinema a la Cruilla [Evento no Facebook]. Disponível em: https://www.facebook.com/ events/1688052071496413/?acontext=\%7B\%22ref\%22\%3A\%223\%22\%2 C\%22ref_newsfeed_story_type\%22\%3A\%22regular\%22\%2C\%22action _ history\%22\%3A\%22null\%22\%7D. Consultado em 26/05/2017.

Col.lectiu Superilla Poblenou [Página no Facebook]. Disponível em: https://www.facebook. com/SuperillaP9/

Compartim Coneixement Col-lectiu [Evento no Facebook]. Disponível em: https://www. facebook.com/ents/1878275819107547/?acontext=\%7B\%22ref\%22\%3A\% $223 \% 22 \% 2 \mathrm{C} \% 22$ ref_newsfeed_story_type $\% 22 \% 3 \mathrm{~A} \% 22$ regular $\% 22 \% 2 \mathrm{C} \% 22$ action_history\%22\%3A\%22null\%22\%7D. Consultado em 26/05/2017. 
De Certeau, M. (1999). The practice of everyday life. Trad. Steven F. Rendall. Berkley, CA: University of California Press.

Duany, A. (2015) Apresentação. In M. Lydon \& A. Garcia, Tactical urbanism: short-term action for long-term change (pp. xi-xii). Nova York: Island Press.

El Domini Públic: \#Superillapilot (2016, 6 de setembro). Esarq-School of Architecture. Disponível em: https://architecture.uic.es/2016/09/06/el-domini-public-superilla pilot-supereixample/. Consultado em 26/05/2017.

Feireiss, K. \& Hamm, O. G. (eds.) (2015). Transforming cities. Urban interventions in public space. Berlim: Jovis Verlag.

Festes de Maig a la Superilla Poblenou [Evento no Facebook]. Disponível em: https://www. facebook.com//604918696371025/?acontext=\%7B\%22ref\%22\%3A\%223\%22 $\% 2 \mathrm{C} \% 22$ ref_newsfeed_story_type $\% 22 \% 3 \mathrm{~A} \% 22$ regular\%22\%2C\%22action_ history\%22\%3A \%22null\%22\%7D. Consultado em 26/05/2017.

La superilla del Poblenou culmina la prova pilot i s'inicien els usos definitius (2017, 12 de abril). Nació Digital. Disponível em: http://www.naciodigital.cat/noticia/129187/superilla/ poblenou/culmina/prova/pilot/inicien/usos/definitius. Consultado em 12/06/2017.

Lydon, M. \& Garcia, A. (2015). Tactical urbanism: short-term action for long-term change. Nova York: Island Press.

Márquez, C. (2017, 6 de novembro). La inquietud de los barceloneses por el turismo y la vivienda se dispara. El Periódico. Disponível em: http://www.elperiodico.com/es/ barcelona/20171106/barcelona-turismo-problema-mas-grave-6404679. Consultado em 26/05/2017.

Martínez, C. (2016, 12 de setembro). Barcelona inaugura sua primeira "superquadra" voltada para pedestres e ciclistas. Archdaily. Disponível em: https://www.archdaily.com.br/ br/795024/barcelona-inaugura-sua-primeira-superquadra-voltada-para-pedestres-eciclistas. Consultado em 12/06/2017.

Open day '17: una edició radiant i molt participative (2017). Poblenou Urban District. Disponível em: http://www.poblenouurbandistrict.com/open-day-2017-una-edicioradiant-i-molt-participativa/. Consultado em 12/06/2017.

Oswalt, P., Overmeyer, K. \& Misselwitz, P. (2013). Urban catalyst. The power of temporary use. Berlin: DOM Publishers.

Plataforma d'Afectats per la Superilla [Página no Facebook]. Disponível em: https://pt-br. facebook.com/AfectadosPorLasSuperilles/

Presentación SuperBarrio. Diseña tu superilla [Evento no Facebook]. Disponível em: https:// www.facebook.com/ents/1842092762725665/?acontext=\%7B\%22ref\%22\%3A $\% 223 \% 22 \% 2 \mathrm{C} \% 22$ ref_newsfeed_story_type $\% 22 \% 3 \mathrm{~A} \% 22$ regular $\% 22 \% 2 \mathrm{C} \%$ 22action_history\%22\%3A\%22null\%22\%7D. Consultado em 26/05/2017.

Rueda, S. (2013). El urbanismo ecológico. Urban-e, (4). Disponível em: http://urban-e.aq.upm. es/articulos/ver/el-urbanismo-ecol-gico/completo/. Consultado em 26/05/2017.

Rueda, S. (2016, novembro). La supermanzana, nueva célula urbana para la construcción de un nuevo modelo funcional y urbanístico de Barcelona. BCN Ecologia. Agència d'Ecologia Urbana de Barcelona. Disponível em: http://www.bcnecologia.net/sites/ default/files/proyectos/la_supermanzana_nueva_celula_poblenou_salvador_rueda. pdf. Consultado 26/05/2017. 
Soro, S. (2016, 12 de setembro). Barcelona reconfigurarà la superilla del Poblenou davant les queixes dels veïns. Ara.cat. Disponível em: https://www.ara.cat/societat/Barcelonareconfigurara-superilla-queixes_0_1649235205.html. Consultado em 17/09/2018.

Sust, T. \& García, D. (2016, 19 de dezembro). Barcelona anuncia cinco supermanzanas en el Eixample, Les Corts, Gràcia y Horta para el 2018. El Periódico. Disponível em: http://www.elperiodico.com/es/barcelona/20161219/ciu-erc-propuesta-cambiosupermanzana-5700472. Consultado em 26/05/2017. 